\title{
Epistemologie feministyczne. Ku lepszej wiedzy o „kobietach”
}

Feminizm jako projekt zarazem polityczny i naukowy narodził się wraz z konstatacją, że ta dotycząca kobiet wiedza, którą wytwarzano dotychczas i która uchodziła za naukową, jest w rzeczywistości niepełna, zniekształcona i zideologizowana. Badaczki i działaczki postawily sobie wyjściowe pytanie, które do dziś znajduje się u podstaw feministycznych projektów badawczych: jak można wytwarzać lepszą wiedzę o kobietach?

Pierwsza fala odpowiadała na to pytanie w sposób dziś budzący wiele wątpliwości, niemniej skuteczny. Wykorzystując uniwersalistyczny dyskurs oświeceniowy, pierwsze feministki podkreślały, że wiedza nie ma płci - czyli że nie jest symbolicznie upłciowiona czy uwikłana w patriarchalne struktury; jej zniekształcenie to kwestia uprzedzeń, które nie dotykają samej istoty tego, czym jest wytwarzanie wiedzy ${ }^{1}$. Idealny podmiot poznający powinien więc wyzwolić się ze swoich płciowych i klasowych uwarunkowań (jak wiemy, w praktyce projekt oświeceniowy służył konkretnej klasie, grupie etnicznej i płci; potencjał uniwersalistyczny sprawiał jednak, że możliwe było kwestionowanie tego partykularyzmu).

Trzeba było poczekać na drugą falę, by napotkać pierwsze próby zakwestionowania tezy o neutralności wiedzy. Feminizm drugiej fali

1 Zob. np. M. Wollstonecraft, Wotanie o prawa kobiety, tłum. Ewa Bodel i in., Warszawa 2011. 
stanowił składnik przemian, które nastąpiły w naukach społecznych i humanistyce w drugiej połowie dwudziestego wieku - skrótowo można je opatrzyć etykietką konstruktywizmu. Antropologia, socjologia czy językoznawstwo podkreślały rolę schematów kategorialnych w wytwarzaniu tego, co uznajemy za rzeczywistość czy fakty; wiedza stała się czymś nie tyle ograniczanym przez uwarunkowania kulturowe, co przez nie kształtowanym².

Pierwsze, kluczowe interwencje feministyczne są właśnie wyrazem ducha konstruktywistycznego: prace socjologiczne ${ }^{3}$ czy antropologiczne ${ }^{4}$ analizują systemowe uwarunkowania wyznaczające status kobiet jako grupy. Teksty te wykorzystują aparat analityczny istniejących dyscyplin, ale także go przekształcają, zwracając uwagę na luki, przemilczenia czy akceptację niesproblematyzowanych złożeń. Główną innowacją feministyczną w tej fazie jest kategoria płci kulturowej (gender) jako odrębnej od płci biologicznej. Antropolożka Gayle Rubin proponuje pojęcie sex-gender system, rozumiany jako „system urządzeń, za pomocą których społeczeństwo przekształca biologiczną seksualność w wytwory ludzkiej działalności" ". Ujęcie tego, co biologiczne, jako surowego materiału dla kulturowych operacji stanowiło ruch bardzo użyteczny w tym początkowym okresie; potem jednak zaczęto poddawać je surowej krytyce ${ }^{6}$. Rozróżnienie na to, co biologiczne i to, co konstruowane społecznie, pozwalało wprawdzie ukazać przygodny charakter wielu zjawisk uznawanych przez nauki głównego nurtu za niepodważalne; zarazem jednak utrwalało podział na nauki społeczne/humanistykę i nauki przyrodnicze, i w dużej mierze oddawało pole refleksji o płci biologicznej biologii, traktowanej z mieszaniną lekceważenia i nieufności. Dychotomia płeć kulturowa-płeć biologiczna była wtedy jednak nieuniknionym rozwią-

2 Przemiany przygotowane oczywiście przez to, co działo się w humanistyce (przede wszystkim w antropologii) wcześniej, w pierwszej połowie dwudziestego wieku (zob. np. M. Mead, Dojrzewanie na Samoa, w: tejże, Trzy studia, tłum. E. Życieńska, Warszawa 1986).

3 H.M. Hacker, Kobiety jako grupa mniejszościowa, tłum. T. Hołówka, w: Nikt nie rodzi się kobieta, red. T. Hołówka, Warszawa 1982.

4 S.B. Ortner, Czy kobieta ma się tak do mężczyzny, jak „natura” do „kultury”?, w: Nikt nie rodzi się kobieta.

5 G. Rubin, The Traffic in Women. The 'Political Economy' of Sex, w: Toward an Anthropology of Women, red. R. Reiter, New York 1975, s. 159.

6 Zob. K. Krasuska, Jaki gender jest, każdy widzi. Podstawowe terminy, w: Gender. Przewodnik Krytyki Politycznej, Warszawa 2014, s. 48-50; J. Butler, Koniec różnicy seksualnej, tłum. A. Kowalcze-Pawlik, w: Teorie wywrotowe, red. A. Gajewska, Poznań 2012. 
zaniem problemu podporządkowania kobiet; wpisywała się też dobrze w panujący klimat konstruktywistyczny ${ }^{7}$. Trzeba przy tym pamiętać, że konstruktywistycznym badaniom akademickim towarzyszyły podejmowane przez działaczki próby przejmowania wiedzy i praktyki z rąk ekspertów (psychologów, seksuologów czy lekarzy), podtrzymujących patriarchalne założenia typowe dla społecznego zdrowego rozsądku ${ }^{8}$. „Neutralną” wiedzę i praktykę ekspercką zastępowano wiedzą wytworzoną oddolnie, w toku współpracy kobiet-ekspertek i kobiet-odbiorczyń.

Wkroczenie feminizmu w mury akademii zaowocowało pojawieniem się nowych dyscyplin - women's studies i gender studies. Od początku było jasne, że nie chodzi tylko o kobiety; gender jest kategorią relacyjną, nie zakłada istnienia dwóch niezależnych grup - kobiet i mężczyzn, ale zdaje sprawę z ich wzajemnego uwikłania: „każda informacja na temat kobiet jest jednocześnie informacją o mężczyznach, jedno implikuje badanie drugiego"9 (choć trzeba przyznać, że nie zawsze było to widoczne, a niebezpieczeństwo „partykularyzacji” tej perspektywy było nieustannie obecne, na co może wskazywać sama nazwa women's studies jako studiów tematycznych poświęconych konkretnej grupie) ${ }^{10}$.

Postulaty uwzględnienia obecności kobiet i/albo perspektywy genderowej w historii, filozofii i naukach społecznych oznaczały zarówno oddanie sprawiedliwości prekursorkom-naukowczyniom, pracę na rzecz zwiększenia udziału kobiet w uprawianiu tych dyscyplin, jak i refleksję metodologiczną. Szybko okazało się, że aby rzeczywiście uwzględnić perspektywę genderową w danej dyscyplinie, nie wystarczy tylko dodać kobiety

7 Do dziś dualizm ten pozostaje często dobrym (choć bezsprzecznie kompromisowym) rozwiązaniem pozwalającym interweniować na gruncie polityki głównego nurtu, czego świadectwem może być wydany przez „Krytykę Polityczną” Gender. Przewodnik. Jak zapewnia zaniepokojonych opis na okładce: „Płci biologicznej nie da się zmienić, można ją co najwyżej skorygować”. Sama książka zawiera jednak wiele przykładów zakwestionowania oczywistości tego dualizmu (zob. np. teksty Karoliny Krasuskiej, Marii Pawłowskiej i Aleksandry Kanclerz).

8 Zob. D. Haraway, Modest_Witness@Second_Millenium.FemaleMan $\left({ }_{-}\right.$ Meets_OncoMouse ${ }^{\mathrm{TM}}$, New York-London 1997, s. 192-197; Nasze ciata, nasze życie, red. J. Puzewicz-Barska, E. Tomaszewicz, Gdańsk 2004.

9 J.W. Scott, Gender jako przydatna kategoria analizy historycznej, Biblioteka online Think Tanku Feministycznego, http://www.ekologiasztuka.pl/pdf/ f0064scot.pdf, s. 5.

10 Brak tu miejsca, by opisać złożone związki między gender studies, LGBT studies, teorią queer, badaniami nad seksualności i krytyczną teorią rasy; dlatego wspominam o nich, by podkreślić, że zarówno kategoria „kobiet”, jak i samo pojęcie płci kulturowej były kwestionowane i poddawane licznym przewartościowaniom. 
i dobrze wymieszać - konieczne jest przekształcenie sposobu uprawiania tej dyscypliny. W wypadku historii oznaczało to na przykład zwrócenie uwagi na sposób, w jaki płeć jako kategoria może wpłynąć na sposób pisania „tradycyjnej” historii - narodowej, politycznej, społecznej ${ }^{11}$. „Feministki akademickie bardzo wcześnie zaczęły podkreślać, iż studia nad kobietami oznaczają nie tylko wprowadzenie nowych obszarów problemowych, ale także wymuszą krytyczne przemyślenie na nowo przesłanek i standardów prowadzonej pracy naukowej." 12

Otwarte i jednoznaczne zakwestionowanie postulatu naukowej neutralności i zbliżania się do prawdy jako stanowiska zakładającego widok znikąd jest dziełem filozofek: Nancy Hartsock i Sandry Harding. Standpoint theory (co przekłada się najczęściej jako „teorię punktu widzenia”), stanowisko opisane w klasycznym eseju Hartsock, The Feminist standpoint ${ }^{13}$, podkreśla rolę usytuowania podmiotu poznającego jako pozytywnego warunku wytwarzania wiedzy; jak twierdzi autorka, to podmioty podporządkowane/nieuprzywilejowane przez daną strukturę społeczną są zdolne do dostrzeżenia wytwarzających i podtrzymujących ją mechanizmów. Zakwestionowanie dogmatu neutralności i teza, że usytuowanie, osadzenie w kontekście społecznym i politycznym oraz zaangażowanie nie są ograniczeniami, ale warunkami obiektywności, pozwoliło raz na zawsze pozbyć się zarzutu o „upolitycznienie” wiedzy wytwarzanej przez akademicki feminizm (oraz inne dyskursy wytwarzane przez grupy podporządkowane $)^{14}$. Usytuowanie pozwala nam widzieć i wiedzieć więcej i lepiej; zdaniem Harding (oraz rozwijającej tę koncepcje Donny Haraway ${ }^{15}$ ) poznanie to nie mozolne pozbywanie się uwarunkowań związanych z usytuowaniem, ale dokładniejsze mapowanie przestrzeni, w której się znajdujemy, przestrzeni, która z definicji zawiera podmiot poznający ${ }^{16}$.

11 J.W. Scott, Gender, s. 22-28.

12 Tamże, s. 2-3.

13 N. Hartsock, The Feminist Standpoint. Developing the Ground for a Specifically Feminist Historical Materialism, w: Discovering Reality. Feminist Perspectives on Epistemology, Metaphysics, Methodology and Philosophy of Science, red. S. Harding, M. Hintikka, Boston 1983.

14 Marksizm ze swoim założeniem o politycznym/klasowym uwarunkowaniu poznania, będącego zarazem interwencją polityczną, pozostaje dla Hartsock i Harding główną inspiracją.

15 D. Haraway, Wiedze usytuowane. Kwestia nauki w feminizmie i przywilej ograniczonej/częściowej perspektywy, tłum. A. Czarnacka, Biblioteka online Think Tanku Feministycznego, http://www.ekologiasztuka.pl/pdf/f0062haraway1988.pdf.

16 Zob. G.Ch. Spivak, Strategie postkolonialne, tłum. A. Górny, J. Majmurek, Warszawa 2011. 
Z kolei Harding, w The Science Question in Feminism, kreśli zarys feministycznego empiryzmu, perspektywy zdolnej uwzględnić konstruktywistyczne osiągnięcia nauk społecznych w powiązaniu z charakterystycznym dla nauk przyrodniczych naciskiem na empiryczną analizę materialnej rzeczywistości.

Perspektywa feministyczna w naukach przyrodniczych zaznaczyła się głównie w biologii; kwestia płci („biologicznej”, pojmowanej w założeniu jako przeciwieństwo płci kulturowej) jest bowiem bardzo istotna dla tej dyscypliny. Te obszary badawcze, które zazębiają się z naukami społecznymi i humanistyką, zwłaszcza antropologią - biologia ewolucyjna, socjobiologia czy badania dotyczące neurologicznych podstaw zróżnicowania płciowego - aspirują do przedstawienia prawdy na temat istoty płci biologicznej, a jednocześnie pozostają uwikłane w kulturowe i polityczne kontrowersje (często poza świadomością samych badaczy); ich dążenie do wytwarzania neutralnej, nieupolitycznionej wiedzy jest więc szczególnie podatne na krytykę.

Naukowczynie, takie jak Barbara Smuts czy Sarah Blaffer Hrdy, wnoszące oryginalny wkład w prymatologię, teorię antropogenezy i psychologię ewolucyjną, a przy tym dające wyraz swojej świadomości feministycznej ${ }^{17}$, dają przykład tego, że nauki przyrodnicze nie są skazane na redukcjonizm i bezkrytyczne powielanie patriarchalnych uprzedzeń. Badaczki te zwracają uwagę na problematyczność metod (np. dobór próby badawczej) i kwestionują przyjmowane przez badaczy płci męskiej założenia (jak np. założenie, iż to zachowania samców stanowią klucz do interpretacji organizacji społecznej danego gatunku). Z ich badań wyłania się obraz płciowego i gatunkowego zróżnicowania kategorii takich jak sukces reprodukcyjny, dominacja czy hierarchia społeczna ${ }^{18}$. Ich perspektywa pozwala na postawienie pytania o relację między płcią biologiczną i kulturową - już poza męczącym sporem o „biologiczny redukcjonizm”. Biologia (zarówno ludzi, jak i innych zwierząt) jawi się tu już nie jako przeznaczenie, ale jako obszar niezbadanych możliwości.

Przezwyciężenie podziału między naukami humanistycznymi i przyrodniczymi stało się rzeczywistością dopiero stosunkowo niedawno; najlepszą

17 Zob. D. Haraway, Primate Visions, New York-London 1989.

18 S. Blaffer Hrdy, Kobieta, której nigdy nie byto, tłum. M. Ryszkiewicz, Warszawa 2005; warto też wspomnieć o pracach Elaine Morgan, która nie jest wprawdzie biolożką, niemniej zrobiła wiele dla popularyzacji alternatywnych koncepcji ludzkiej ewolucji (zob. E. Morgan, Pochodzenie kobiety, tłum. M. Danicka-Kosut, Warszawa 2007; zob. też Małgorzata Danicka, „Myśleliśmy, że pierwszy cztowiek byt Anglikiem" Scenariusze ewolucyjne antropogenezy - wpływ perspektywy feministycznej - Elaine Morgan, http://www.praktykateoretyczna.pl/malgorzatadanicka-\%E2\%80\%9Emyslelismy-ze-pierwszy-czlowiek-byl-anglikiem. 
ilustracją tego przełomu są prace Donny Haraway. Proponowane przez nią kategorie naturokultur oraz aktorów materialno-semiotycznych ${ }^{19}$, postulujące nierozerwalny splot znaczeń i materialnych układów, stanowią przykład produktywnego zderzenia feministyczno-queerowego poststrukturalizmu z niepozytywistyczną filozofią nauki. Zarówno jej starsze, jak i nowsze prace wpisujące się w nurt nowego materializmu ${ }^{20}$ dowodzą, że w wypadku przejścia od konstruktywizmu do postkonstruktywizmu feminizm znowu znajduje się w centrum przemian metodologicznych, łącząc akademicki nacisk na specjalizację i złożoność z równie istotnym wymogiem interdyscyplinarności, niezbędnej przy tworzeniu wiedzy zaangażowanej.

Zebrane przez nas teksty próbują na bardzo różnych polach rozwijać właśnie taką perspektywę. Na przykład artykuł Feminist Aliens, Memoirs from the Margins. A Caribbean "Feminist's” Experience in Western Feminism poświęcony jest sposobom produkcji i dystrybucji wiedzy na temat kobiet z krajów rozwijających się. Autorka, Andrea N. Baldwin, zauważa, że choć ich doświadczenia zostały włączone w obszar zainteresowań zachodniego feminizmu, to jednak nie nastąpiła dotychczas - niezbędna dla przekształcenia relacji władzy - zmiana w przepływie informacji i idei. Przepływ ten, odbywając się w jednym kierunku - z Zachodu do krajów rozwijających się, sprawia, że zachodnie feministyczne epistemologie stają się karykaturą epistemologii, którą usiłowały zakwestionować. W podobnym duchu przeprowadza rewizję zachodniego feminizmu Monika Borys. Próbując odpowiedzieć na pytanie, jak polski feminizm mógł włączyć w obszar swoich badań i działań mieszkanki wsi, postuluje ona, za bell hooks, epistemologię marginesu. Oparta na założeniu, że różne formy opresji (takie jak seksizm, klasizm czy rasizm) przenikają się, oddziałują na siebie, a także wywodzą się z podobnych źródeł, wymierzona byłaby ona w epistemiczną przemoc, jaka określa reprezentacje podporządkowanych innych. Dział analiz zamyka artykuł AnyLouise Keating i Kimberly C. Merendy. Jest on bardzo ciekawą próbą przekroczenia paradygmatu antropocentrycznego z jego sztywną granicą pomiędzy tym, co ludzkie i tym, co nieludzkie. Keating i Merenda kwestionują jego zasadność, wspierając się między innymi argumentami z zakresu współczesnej wirusologii. Człowiek w tej perspektywie jawi

19 D. Haraway, Manifest gatunków stowarzyszonych, tłum. J. Bednarek, w: Teorie wywrotowe.

20 Zob. np. Material Feminisms, red. S. Alaimo, S. Hekman, Bloomington 2008; New Materialisms, red. D. Cooole, S. Frost, Durham 2010; C. Asberg, N. Lykke, Feminist Technoscience Studies, "European Journal of Women's Studies" 2010, nr 17. 
się nie jako podmiot oddzielony od obiektu, lecz jako istota złożona $\mathrm{z}$ innych istot, nie indywiduum, lecz zbiorowy wysiłek.

Dział „Praktyki badawcze” akcentuje z kolei rolę, jaką w produkcji wiedzy pełni wspólnota. Autorki tekstu Stability of Shifting Ground. Feminist Ethnography and Practice interesuje moment stabilizowania się znaczeń, który zaciera niestabilność pozycji tego, kto je tworzy. Ten moment próbują one uchwycić, nadając swojemu tekstowi formę dialogu, pozwalającą pomyśleć o wiedzy w kategoriach zmiany, procesu raczej niźli gotowego zespołu danych. Podobny punkt widzenia przyjmują autorki artykułu Co-writing, Co-knowing. Transforming Epistemologies. Opisawszy charakter i cele stworzonej przez siebie grupy badaczek, zarysowują następnie stojący za nią projekt epistemologiczny. W miejsce modelu opierającego się na odcięciu, bezstronności i kontroli proponują one poznanie powiązane i relacyjne, które tożsame jest $\mathrm{z}$ transformacją podmiotu poznającego.

Dział „Lektury” składa się z trzech tekstów. Pierwszy, autorstwa Katarzyny Szopy, czerpiący inspiracje z feminizmu materialistycznego, łączy wypracowaną przez Sarę Ahmed i Jackie Stacey koncepcję „myślenia poprzez skórę" z metaforyką skórną obecną w poezji Joanny Mueller. Autorka pokazuje, jak w obu tych dyskursach dochodzi do odrzucenia dualistycznej koncepcji epistemologii i wyłonienia się modelu poznania, który daje się opisać za pomocą takich terminów jak intra-akcja, „sprawcze oddzielenie”, „zewnętrzność-wewnątrz-fenomenu”. Artykuł Małgorzaty Myk omawia dorobek trzech współczesnych poetek amerykańskich: Lyn Hejinian, Leslie Scalapino i Carli Harryman. Ich twórczość, zdystansowana od écriture féminine, odznacza się przekroczeniem dualizmu praktyka/teoria. Skupiona na roli języka w procesie poznania, może być, jak dowodzi autorka, traktowana w kategoriach poetyckiej epistemologii. Trzecia z obecnych w tym dziale autorek, Clara Zgoła, przeprowadza natomiast analizę ostatniej powieści Virginie Despentes, Apocalypse bébé. Autorka, sięgając po koncepcje geopoetologiczne, koncentruje się na relacjach pomiędzy bohaterami a przestrzenią - sprawdza, na ile pojawia się ona u Despentes jako obiekt poznania, a na ile definiuje sam podmiot, którego poznanie zawsze jest zależne od zajmowanej pozycji.

Przy okazji numeru opublikowaliśmy także tekst Małgorzaty Danickiej zdający sprawę z emancypacyjnego potencjału pisarstwa feministycznej darwinistki Elaine Morgan. Danicka przekonuje, że nie powinnyśmy ulegać hegemonicznej wizji tego czym jest nauka i mimo zawłaszczenia przez seksistów teorii ewolucji, udowadniać, że nauka, a w szczególności teoria Darwina nie są wrogami równości, ale najlepszymi sojusznikami $\mathrm{w}$ walce o jej realizacje. 
Cytowanie: Joanna Bednarek, Katarzyna Czeczot, Epistemologie feministyczne. Ku lepszej wiedzy o „kobietach”, „Praktyka Teoretyczna” nr 4(10)/2013, http://www.praktykateoretyczna.pl/PT_nr10_2013_ Epistemologie_feministyczne/00.Wstep.pdf (dostęp dzień miesiąc rok) 